\title{
Community Social Construction on Islamic Holidays in Ponorogo Regency During the Pandemic
}

\author{
Nufikha Dwi Pertiwi ${ }^{1, *}$, Agus Machfud Fauzi ${ }^{2}$
}

\author{
${ }^{1}$ Universitas Negeri Surabaya \\ ${ }^{2}$ Universitas Negeri Surabaya \\ *Corresponding Author. Email:nufikha.18005@mhs.unesa.ac.id
}

\begin{abstract}
At the moment the world is being hit by the covid-19 pandemic virus. It affects all aspects of life such as economic, social andcultural. The impact was also experienced during the Islamic Holiday in Ponorogo Regency. With the increase in the pandemic virus that occurred, the commemorations of Islamic holidays in Ponorogo changed. The change was felt by people who couldnot follow the traditions during the Islamic Holiday in Ponorogo Regency. The purpose of this study is to find out the social construction of the community about islamic holidays in Ponorogo Regency. The theory used in this study is the social construction of Peter L. Berger. The method used in research is qualitative research methods with data collection techniques by observation and interview. The results of the study are that there is a change in behavior in the community during the pandemic in commemoration of The Islamic Holiday in Ponorogo Regency. There is a process of internalization, objectivation, and externalization in the community about the celebration of Islamic Holidays.
\end{abstract}

Keywords: Covid-19, Policy, Social Construction, Community

\section{INTRODUCTION}

At this time the world is being hit by the covid-19 outbreak including the country of Indonesia. With this, the impact is quite large both in terms of economic, social and cultural. Until now, many victims died due to the outbreak of pandemic covid-19. The government has implemented several policies including Social Distancing, Work From Home and PSBB (Large-Scale Social Restrictions). The effect of the PSBB is to regulate the holidays and workplaces, religious activities, activities of public places or facilities, socio-cultural activities and restrictions on activities related to defense and security aspects. According to Muttaqin, et al,pros and cons occur in the heterogeneity of understanding mechanisms in the implementation of worship during [1]

Religious behavior experienced by Muslims can be seen in carrying out worship activities and commemorations of Islamic holiday [2] The increasing spread of the covid-19 virus is fearing every community in the world, not least in Indonesia until now. That way, the government provides a strict policy so that the spread of the corona virus can be minimized. This strict policy hasan impact on cultural traditions to commemorate Islamic holidays. Traditions and culture incommemorating the feast of isalm in each region aredifferent.

The rich cultural traditions of Indonesian people is a form of gratitude in commemorating Islamic holidays [3]. One of them is in Ponorogo Regency which has various traditions to commemorate Islamic holidays such as Suroan (1 muharram),Larung Sesaji and other rituals. For the people of Java night 1 muharram or 1 Sura has an important and sacred meaning. According to Bowo, et al. that 1 Muharram or 1 Sura has a spiritual meaning that is an embodiment of time that is believed to have an impact on human [4] The celebration of Islamic holidays in Ponorogo Regency is a commemoration that is awaited by the people of Ponorogo because of some traditions and cultures carried out [5]. According to Japarudin in his research, the traditions and rituals carried out area form of habit in the community in performing as well as traditions and rituals in the month of Muharram [6] 
This pandemic condition has changed the habits of Muslims in commemorating Islamic holidays and worship activities. For example, restrictions on worshipers praying in mosques and banning the existence of traditions to commemorate Islamic holidays because it has the potential to cause crowds. According to Ghofur \& Subahri that the role of the media in both Indonesia and other countries that have a majority islamic population, it is necessary to know how wise isalm in the face of emigrants[2] With this, the celebration of Islamic holidays at this time cannot be carried out like the previous year. [7]

Covid-19 has provided major changes for the community to interact and carry out religious activities. There needs to be awareness in the community to comply with health protocols that have been proclaimed by the government. By reducing the crowd in the community will have a big impact on each individual. As stated by The Ponorogo Police Chief that, in commemoration of the celebration of Muharram Month some police personnel carry out security to prevent the spread of covid-19 [8] Narrow community activities resulted in religious activities and holiday commemorations in Indonesia could not be carried out.

That way, the religious perspective has a strong influence in the community in resuscitating intaking action in the face of covid-19. With many activities and warnings in the community have changes in both implementation and activities that are limited to making changes in society. The difference between this study and previous researchis how to see the community responding to changes due to pandemics in commemorating Islamic holidays in Ponorogo Regency in review of community social construction. So researchers havedetermined the problem of research, namely how the Social Construction of The Community About Islamic Holidays in Ponorogo Regency during the Pandemic.

\section{METHODS}

This research uses qualitative research methods. The characteristic of qualitative research isthat researchers act as an important instrument in data collection at [9] The subject of the study is the people of Ponorogo Regency. The location of the study conducted in Ponorogo Regency, East Java. The reason researchers chose the location is that researchers want to know how the social construction of the community about the Islamic Holiday in Ponorogo Regency. It takes a month to produce valid and accurate data.
The data sources used in this study are primary data sources and secondary data sources. Inprimary data sources the results of the data are obtained through interviews and observations. The advantage of this data source is that the data obtained is more accurate because the data is obtained by observing the phenomenon that occurs. However, the disadvantages of primary data sources, namely the way of implementing and collecting data takes along time. While secondary data sources are the results of data obtained through the existence of intermediaries. The intermediary in question here is the media. The media here is a lot like photos, archives, books and others. This data source can be obtained by visiting museums, libraries, and so on. The advantage of this data source is that the costs incurred are relatively cheap. However, this data source also has a disadvantage, namely usually the data obtained is no longer relevant to the phenomenon and the development of the times.

Data collection techniques are very important in a study. Researchers choose data collection techniques by means of observation and interview. Observation is a systematic process in which it records human behavior, objects and events without any questions from researchers. This process can turn facts into data. Interviewsare interviewedto obtain information related to facts, beliefs, feelings, desires, and so on to meet research objectives. Interviewing is an important process in a qualitative study. The interview was conducted online because at this time there is a Pandemic Covid-19 so it cannot meet with informants in person.

This study uses the Theory of Social Construction by Peter L. Berger and Thomas Luckman. Social Construction is a form of social process through action and interaction, in which individuals create continuously so that a reality is formed that is possessed and experienced subjectively. The construction process by looking at the perspective of Peter L. Berger and Luckman's theory is formed through three stages, namely externalization, objectivity, and internalization. Externalization is a stage of self-adjustment with the socio-cultural world as a human product. Meanwhile, objectivity is the result that has been done from externalization activities both mental and physical. The last is internalization where this stage of individuals can identify themselves into the institution or organization of which the individual is a [10] 


\section{RESULTS AND DISCUSSION}

\subsection{Islamic Holidays in Ponorogo Regency Duringthe Pandemic}

Islam is the majority religion in Indonesia. Indirectly has a major influence on aspects of daily life, in this case the Islamic community in Java, especially in Ponorogo Regency. In[11] behavior. Each religion, both Islam has its own tradition in commemorating islamic holidays. The term 'Tradition' here is an understanding as knowledge, kebiasaan raktek that has been inherited down hill.

The values in Islam contained have values and meanings that are important to everyday life. Inaddition, the values contained in isalm religion can be seen from activities that are social and religious. It can be observed from celebrations such as circumcision, aqiqah, death, to establishing a house and much more. There are various religious traditions including the celebration of Islamicholidays such as Eid al-Fitr, Eid al-Adha, 1 Muharram, 10 Muharram, Muludan, Rajaban, NifsuSha'ban, to Nuzulul[11] These activities are done as a form of gratitude to Allah SWT. This series of activities has become a habit or tradition in thecommunity so that if it is not done in terms of the people of Ponorogo Yaknu Regency 'less afdhol'.

Religion has an important role in the development of society. The celebration of Islamic holidays in Ponorogo during this pandemic is experiencing obstacles. This is because the government has set rules not to hold activities that trigger crowds. The Indonesian government has appealed that it has implemented a large-scale social restriction policy or [12]coronavirus. In addition to these policies, the government has appealed to the public to implement social distancing where it affects public health status and minimizes the spreadof the corona virus.

These policies brought a number of islamic holiday celebrations in Indonesia to a standstill. With this, the community needs to adapt to the new environment and atmosphere because of the influence of the corona virus. The increasing spread of the corona virus makes a number of celebrations in Ponorogo Regency stopped, as in 1 Muharram, the activities of Suro-an. The implementation of Suroan in Ponorogo Regency before the pandemic took place in accordance with the procedures for the implementation of Suro, namely the Performance of the National Festival reyog Ponorogo, then continued the day before 1 Suro held the Cross
History Parade and Kirab Pusaka, then on the night of 1 Suro held the closing of the National Festival Reyog Ponorogo, and on the 1st of Suro held Larung Sesaji in Telaga Ngebel. This islamic holiday celebration activity has niali and y ang meaning contained such as religious values, spiritual values, beauty values, social values and much more.

The commemoration of Islamic Holidays at the time of this pandemic is a challenge for the government and the public in implementing in accordance with health protocols. With the implementation of social distancing, the commemoration of Islamic holidays in Ponorogo Regency continues to run smoothly. The public can comply with regulations that have become government policies related to the covid-19 pandemic. Such activities such as for example, namely during eid al-Fitr, where on that day the community continues to perform Salat Ied but still by obeying protokol health and keep a distance. In addition, the policy implemented by the government is related to the friendship during Eid al-Fitr, where the government does not recommend to cooperate directly because it minimizes contact with other individuals.

Pandemic covid-19 has had an impact on people's lives both in terms of religion, social culture, and others. There is concern in the community about the increasing spread of covid19in Indonesia. These concerns make the behavior of people who are more concerned about the environment, cleanliness and health. That way, the change has a big impact on the celebrations of Islamic holidays in Ponorogo Regency. Public perception of the coronavirus caused a number of traditions and celebrations in Ponorogo Regency could not be carried out.

The appeal to celebrate the Islamic Holidayhas been made by the government. The appeal has been published through online and offline media. With this, it is expected that the public will still adhere to health protocols in the implementation of Islamic holidays that will in fact have a major influence and cause crowds. Religious traditionssuch as the commemoration of Islamic Holidays area form of gratitude and a form of cultural preservation during the pandemic.

The enthusiasm of the community in the implementation and implementation of Islamic holidays in Ponorogo Regency is very high. With this, the Ponorogo Regency government has a policyin the implementation of Islamic Holidays. The policy is in the form of the implementation of the Islamic holiday 1 Muharram which is carried out byobeying the protocol and is not allowed to 
pretisipasi community that causes crowds. The policy carried out by the Ponorogo Regency government is a formof analyzing the increasing spread of the corona virus. The public realizes that this pandemic is a barrier for people to be enthusiastic in the celebration of Islamic Holidays.

\subsection{Community Social Construction on IslamicHolidays in Ponorogo Regency During pandemic}

The theory of social construction is a theory put forward by Peter L. Berger and Thomas Luckman. This theory was motivated by shamanagnny in the Phenomenological tradition of Husserl who loudly rejected positivistic [13] In Ghofur \&Ampahri's research that Berger and Luckman said the actions and interactions carried out are a change created and maintained by community [2]institutions. However, in reality all are constructed and defined subjectively through interaction on both.

Objectivity can occur through repetition of interactions and activities given by others so that it is defined subjectively. The contruksi process, which is developed by the theory of Berger and Luckman, there are three dialectics of three forms that become the entry concept,namely subjective reality, simbolyc reality, and objective reality. In addition, in the theory of social construction also takes place a process that is divided into three, namely externalization, objectivity, and internalization.

\subsubsection{Externalization is an adjustment to socio- cultural as a product of man. \\ Externalization is a usaha for self-adjusting} in the environment. This is the basic thing owned by masnusia so that it can promote itself where it is. This adjustment is in accordance with the current situation that is experiencing a covid-19 pandemic. However, people's perspectives related to the covid-19 virus form a negative perpsektif and change daily life.

This change in behavior at the externalization stage is a human self-expression dueto changes that occur before and after the covid-19 pandemic. Humans are required to adapt. The adaptation does not just happen, there must be adjustments that change all community activities, such as islamic holiday activities in Indonesia.

This external process is further strengthened by government policies related to activities that cause crowds. The policy has an impact on religious activities and the commemoration of Islamic Holidays in Ponorogo Regency. This policy has a great influence in commemorating Islamic holidays such as on 1 Muharram. Activities 1 Muharram or Suro-anin Ponorogo Regency have traditions and customs to carry out a number of traditions such as Bedol Pusaka, Kirab Pusaska, Larungan. In these activities will trigger a crowd of people so that in government policy at the time of this pandemic, the activity is carried out but in accordance with health protocols. The public realizes that the activities with this pandemic activities carried out are different from before the covid-19.

\subsubsection{Objectivation $i$ is a social intercation in which in the inter subyektif world is institutionalizedor institutionalized.}

Objectivation is an outcome that has been achieved from human activities. This process is often called social interaction through institutionalization. In the process of institutionalization, the agent has the task of rikhis subjectiveity into an objective world where it is through pesky interactions that can be builttogether.

This process of objectivation is a social interaction that will not be separated from social conflicts that will form subjectiveization in uncertain conditions at the time of the covid19 pandemic. In this pandemic is often encountered and heard by the spokesman of the Task Force handling Covid-19 who initiated to comply with health protocols and stay away from crowds. Therefore, activities that trigger the crowd to be stopped first to minimize the spread of the virus is getting higher. The number of covid-19 spreaders that continue to increase every day keeps the government and TASK FORCE still carrying out campaigns to comply with health protocols.

During a pandemic likethis, proses sobjektivation is first done by economic drivers such as mask manufacturers who increase due to the impact of this pandemic. The community objectivized by way of behavior formation due to the covid-19 pandemic carried out by responding to government regulations that are on social media.

\subsubsection{Internalization is a way of identifying oneselfin the midst of social institutions.}

In the process of internalization, each individual has a different dimension of alignment. In this internal phase it will form an identity. This identity is shaped by social processes.

In activities at the time of this 
pandemic, people are more likely to try to accept reality. This is due to the increasingly strict government to carry out a number of activities. Regardless of the policy, the community is more likely to carry out religious activities with solemnity and strengthen each other's brotherhood. Although at the time of this pandemic can only be done online, but the enthusiasm of the public in celebrating the Islamic Holiday has not changed.

Changes in activities during the celebration of Islamic Holidays are carried out to minimize the penyebaran virus covid-19. With celebratory activities that are only followed by a few important people make a number of Islamic holiday activities in Ponorogo Regency continue to run smoothly. Inaddition, changes in behavior at the time of this pandemic have changed customs and traditionsto commemorate the Islamic Holiday in Ponorogo Regency. In the process of internalization, society has in fact gained wisdom in every circumstance. Masyarakat canadapt tothe circumstances at the time of the pandemic to carry out Islamic Holiday activities.

Changes in activities during the celebration of Islamic Holidays are carried out to minimize the penyebaran virus covid-19. With celebratory activities that are only followed by a few important people make a number of Islamic holiday activities in Ponorogo Regency continue to run smoothly. Inaddition, changes in behavior at the time of this pandemic have changed customs and traditionsto commemorate the Islamic Holiday in Ponorogo Regency. In the process of internalization, society has in fact gained wisdom in every circumstance. Masyarakat canadapt tothe circumstances at the time of the pandemic to carry out Islamic Holiday activities.

\section{CONCLUSION}

From this research it can be concluded that, the people of Ponorogo Regency in commemorating Islamic holidays such as 1 Muharram there are differences. This is because at this time there is a pandemic, so the government issued policies to comply with health protocols and minimize crowds. Changes in behavior made by the people of Ponorogo Regency is a form of adaptation at the time of the pandemic.

These adaptations also have an impact on behavior changes such as religious activities, schools, work and much more.
The process of externalizing the community in this social change is carried out because of information related to covid-19, both from the government and the covid-19 task force. This makes activities in the community can be done by complying with health protocols. With this, the community objectivity by forming behavior and responding to government policies. Islamic Holiday celebration activities at the time of the pandemic experienced differences because of this, the community can accept and respond to regulations made by the government related to the covid-19 pandemic. Furthermore, the process of internalization in the community atthe time of this pandemic is performed by taking wisdom in every situation. By accepting these, religious activities can be performed in accordance with health protocols.

\section{ACKNOWLEDGMENT}

The author would like to thank the lecturers and friends who have provided guidance and support. The authors would also like to thank all the informants involved in this research interview.

\section{REFERENCES}

[1] H. Muttaqin, K. Wahidin, M. A. Maulana, and J. Juarsih, "PEMBERDAYAAN JAMAAH MASJID DAN PENANGGULANGAN DAMPAK PANDEMI COVID-19 (Studi Lapangan Masjid Baitul Mukhlisin, Desa Pangkalan, Kecamatan Ciawigebang, Kuningan)," Nufus, vol. 2, no. 1, pp. 58-76, 2020.

[2] A. Ghofur and B. Subahri, "Konstruksi Sosial Keagamaan Masyarakat Pada Masa Pandemi Covid-19," Dakwatuna J. DakwahDan Komun. Islam, vol. 6, no. 2, p. 281, 2020, doi: 10.36835/dakwatuna.v6i2.636.

[3] A. Arifinsyah, R. Ryandi, and M. Manshuruddin, "Pesantren Religious Paradigm: Aqeedah, Plurality, and Jihad," J.Soc. Media, vol. 3, no. 2, p. 278, Oct. 2019, doi: 10.26740/jsm.v3n2.p278298.

[4] R. T. Bowo, J. Pendidikan, A. Islam, F. Tarbiyah, and D. A. N. Ilmu, "Nilai-Nilai Pendidikan Islam Dalam Tradisi PeringatanTahun Hijriyah," Inst. Agama Islam NegeriSalatiga, 2015.

[5] N. Karerina, A. Ifadah, S. A. Arisholina, A. Wulaningsih, L. Ricard, and A. M. Fauzi,

"Konstruksi Masyarakat pada Tradisi Nyajen Sebagai Usaha Keberhasilan 
Cakades Jelang Pilkades," J. Penelit. Agama, vol. 22, no. 1, pp. 103-114, Jun. 2021, doi: 10.24090/jpa.v22i1.2021.pp103-114.

[6] J. Japarudin, "Tradisi Bulan Muharam Di Indonesia," Tsaqofah Dan Tarikh J. Kebud.Dan Sej. Islam, vol. 2, no. 2, p. 167, 2017, doi: 10.29300/ttjksi.v2i2.700.

[7] Y. P. Dwihayuni and A. M. Fauzi, "The motive for the action of online gambling as an additional livelihood during social restrictions due to the Covid-19 pandemic,"

J. Sosiol. Dialekt., vol. 16, no. 2, p. 108 , Aug. 2021 , doi: 10.20473/jsd.v16i2.2021.108-116.

[8] kanalindonesia.com, "Hadapi Bulan Muharam 1442, Polres Ponorogo Apel Gelar Pasukan," kanalindonesia.com, Indonesia, 2020.

[9] M. P. Dr. Wahidmurni, "Pemaparan Metode Penelitian Kualitatif," pp. 1-17, 2017.

[10] R. Ahmad, N. Irchamniah, O. Pujiana, and $\mathrm{J}$.

H. G. Purwasih, "Konstruksi Sosial Dalam Keluarga Pengemis Di Kecamatan Sukun Kota Malang," J. Sosiol. Pendidik. Humanis, vol. 3, no. 1, p. 47, 2019, doi: 10.17977/um021v3i1p47-54.

[11] D. Ridwan, "MODEL ALTERNATIF PENDIDIKAN ISLAM

TRANSFORMATIF (Studi Nilai-Nilai Pendidikan Islam dalam Tradisi Ambengan Pada Peringatan Hari

Besar Islam di Desa Brunorejo Purworejo)," Millah, vol. 15, no. 2, pp. 249-282, 2016, doi: 10.20885/millah.vol15.iss2.art4.

[12] P. A. Ahadi, Casman, and Nur'aini, "Pengaruh Kebijakan Social Distancing Pada Wabah Covid-19 Terhadap Kelompok

Rentan Di Indonesia," J. Kebijak. Kesehat.Indones. JKKI, vol. 09, no. 02, pp. 61-67, 2020.

[13] F. A. Dharma, "Konstruksi Realitas Sosial:Pemikiran Peter L. Berger Tentang Kenyataan Sosial," Kanal J. Ilmu Komun.,vol. 7, no. 1, pp. 1-9, 2018, doi: 10.21070/kanal.v6i2.101. 